\title{
Evaluasi Kepatuhan Pajak Berdasarkan Perilaku Data Keuangan dan Non Keuangan (Studi Kasus pada KPP Jakarta)
}

\author{
Bayu Maulana Muhammad ${ }^{1}$ \\ Fakultas Ekonomi dan Bisnis \\ Universitas Indonesia, Indonesia
}

\author{
Aruna Wirjolukito ${ }^{2}$ \\ Fakultas Ekonomi dan Bisnis \\ Universitas Indonesia, Indonesia
}

\section{ABSTRAK}

Tujuan dari penelitian ini adalah untuk mengevaluasi kepatuhan pajak berdasarkan perilaku data keuangan dan non keuangan WP. Penelitian ini diharapkan dapat bermanfaat sebagai bahan evaluasi mengenai tingkat kepatuhan pajak dari Wajib Pajak. Penelitian ini menggunakan metode studi kasus (single case) dan menggunakan metode gabungan/kombinasi (mixed method). Analisis deskriptif digunakan untuk menganalisis data dari objek penelitian berupa single case unit analysis. Hasil penelitian ini menunjukan adanya kendali perilaku yang dipersepsikan dari Wajib Pajak yang menunjukan perilaku kepatuhan pajak yang rendah. Kombinasi dari analisis data keuangan dan non keuangan dari Wajib Pajak menghasilkan evaluasi yang bermanfaat dalam menentukan tingkat kepatuhan pajak. Berdasarkan hal tersebut, rendahnya capaian realisasi penerimaan pajak dan tingginya kinerja pemeriksaan pajak dipengaruhi secara langsung oleh perilaku kepatuhan pajak yang rendah dari Wajib Pajak.
\end{abstract}

Surel : baeyou@gmail.com

Kata Kunci: Kepatuhan Pajak; Perilaku; Data Keuangan; Data Non Keuangan.

\section{Evaluation of Tax Compliance Based on Behavior of Financial and Non-Financial Data (Case Study at KPP Jakarta)}

\section{ABSTRACT}

The purpose of this research is to evaluate tax compliance based on the behavior of taxpayers' financial and non-financial data. This research is expected to be useful as material for evaluating the level of tax compliance of taxpayers. This study uses a case study method (single case) and uses a mixed method. Descriptive analysis is used to analyze data from the research object in the form of a single case unit analysis. The results of this study indicate the perceived behavior control of taxpayers that shows low tax compliance behavior. The combination of analysis of financial and non-financial data from taxpayers produces a useful evaluation in determining the level of tax compliance. Based on this, the low achievement of tax revenue realization and high tax audit performance is directly influenced by the low tax compliance behavior of taxpayers.

Keywords: $\quad$ Tax Compliance; Behavior; Financial Data; NonFinancial Data.

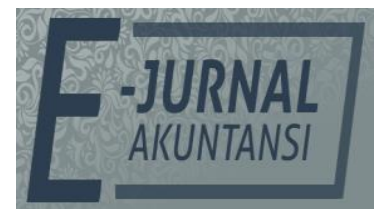

e-ISSN 2302-8556

Vol. 31 No. 1

Denpasar, Januari 2021

Hal. 116-129

DOI:

10.24843/EJA.2021.v31.i01.p09

PENGUTIPAN:

Muhammad, B.M., \&

Wirjolukito, A. (2021).

Evaluasi Kepatuhan Pajak

Berdasarkan Perilaku Data

Keuangan dan Non

Keuangan (Studi Kasus pada

KPP Jakarta). E-Jurnal

Akuntansi, 31(1), 116-129

RIWAYAT ARTIKEL:

Artikel Masuk:

13 Oktober 2020

Artikel Diterima:

20 Januari 2021

Artikel dapat diakses : https://ojs.unud.ac.id/index.php/Akuntansi/index 


\section{PENDAHULUAN}

Pajak merupakan tulang punggung nasional dan menjadi salah satu komponen yang sangat penting bagi pendapatan negara (Kementerian Keuangan, 2016). Berdasarkan data Kementerian Keuangan Republik Indonesia, kontribusi ratarata target penerimaan pajak terhadap total target penerimaan negara sejak tahun 2011 hingga 2017 adalah sebesar 80\% (Kementerian Keuangan, 2019). Kinerja penerimaan pajak menggambarkan jatuh bangunnya suatu negara dalam mengumpulkan pendapatan (APBN) untuk membiayai kegiatan operasionalnya (Kementerian Keuangan, 2016).

Tabel 1. Beberapa Indikator Kinerja DJP Tahun 2015-2017

\begin{tabular}{lccc}
\hline \multirow{2}{*}{ Indikator Kinerja } & \multicolumn{3}{c}{ Tahun } \\
\cline { 2 - 4 } & 2015 & 2016 & 2017 \\
\hline Realisasi penerimaan pajak & $81,97 \%$ & $81,60 \%$ & $89,68 \%$ \\
Realisasi kepatuhan Wajib Pajak Badan dan Orang & $60,00 \%$ & $63,15 \%$ & $62,96 \%$ \\
Pribadi (non karyawan) & & \\
Tingkat efektivitas pemeriksaan pajak & $92,94 \%$ & $93,87 \%$ & $92,81 \%$ \\
\hline
\end{tabular}

Sumber: Laporan Kinerja DJP, 2016 dan 2017

Tabel 1, menunjukkan bahwa sejak tahun 2015 hingga 2017, realisasi penerimaan pajak belum mencapai hasil yang optimal terhadap target penerimaan pajak. Sebaliknya, kinerja pemeriksaan pajak meningkat pada rentang waktu tersebut. Saputri \& Kiswara (2019) berpendapat bahwa pelanggaran pajak menjadi penyebab belum optimalnya penerimaan pajak di Indonesia. Pelanggaran pajak digambarkan dalam bentuk rendahnya tingkat kepatuhan pajak. Dengan demikian, tingkat kepatuhan pajak memiliki pengaruh penting terhadap realisasi penerimaan pajak dan kinerja pemeriksaan pajak.

Penelitian ini merupakan sebuah studi kasus mengenai kepatuhan pajak. Kepatuhan pajak yang rendah ditengarai menjadi penyebab belum optimalnya penerimaan pajak dan meningkatnya kinerja pemeriksaan pajak. Menurut Ilyas \& Wicaksono (2015), pelaksanaan sistem self-assessment akan berjalan dengan baik apabila Wajib Pajak ("WP") memiliki tingkat kepatuhan yang tinggi dan didukung dengan pemeriksaan pajak. Surat Pemberitahuan (SPT) merupakan wujud dari penerapan sistem perpajakan self-assessment. SPT juga merupakan bentuk kepatuhan WP dalam memenuhi kewajiban perpajakannya. Informasi yang terdapat pada laporan keuangan atau pembukuan WP menjadi sumber penting dalam pengisian SPT. Berdasarkan hal tersebut, SPT dan laporan keuangan yang disusun oleh WP diharapkan dapat menggambarkan kepatuhan pajak dari WP.

Penelitian ini dimotivasi oleh fenomena rendahnya tingkat kepatuhan pajak di Indonesia. Fenomena tersebut mengakibatkan belum optimalnya realisasi penerimaan pajak dan meningkatnya kinerja pemeriksaan pajak. Rendahnya tingkat kepatuhan pajak ditengarai karena adanya niat dari WP untuk menunjukan perilaku kepatuhan pajak yang rendah. Menurut Saputri \& Kiswara (2019), niat WP untuk melakukan pelanggaran pajak memiliki pengaruh signifikan terhadap perilaku kepatuhan pajak yang rendah atau tidak patuh. Penelitian lain oleh Saputra (2019) menyatakan bahwa perilaku kepatuhan pajak (rendah atau tinggi) didasari oleh niat WP untuk mewujudkan perilaku tersebut. Berdasarkan hal tersebut, peneliti tertarik untuk melakukan penelitian terkait 
dengan evaluasi perilaku kepatuhan pajak berdasarkan data perpajakan WP, baik data keuangan maupun non keuangan.

Rumusan masalah dalam penelitian ini adalah bagaimana kepatuhan pajak dapat dievaluasi berdasarkan perilaku yang ditunjukan oleh data keuangan dan non keuangan dari WP. Selanjutnya, bagaimana hasil evaluasi tersebut dapat dikaitkan dengan rendahnya realisasi penerimaan pajak dan meningkatnya kinerja pemeriksaan pajak. Tujuan penelitian ini adalah untuk melakukan evaluasi kepatuhan pajak berdasarkan perilaku data keuangan dan non keuangan serta kaitannya dengan fenomena rendahnya realisasi penerimaan pajak dan meningkatnya kinerja pemeriksaan pajak. Penelitian ini diharapkan dapat digunakan sebagai bahan evaluasi terhadap tingkat kepatuhan pajak WP dan bahan pengambilan keputusan dalam menghadapi kondisi rendahnya penerimaan pajak dan meningkatnya kinerja pemeriksaan pajak.

Model perhitungan yang digunakan untuk menguji data keuangan adalah model perhitungan Beneish M-Score ("M-Score"). Model ini ditemukan oleh Messod D. Beneish pada tahun 1999. Menurut Beneish, model ini mudah diterapkan dengan menggunakan data yang diambil dari laporan keuangan. Berdasarkan bukti-bukti yang ada, data akuntansi sangat bermanfaat dalam mendeteksi adanya manipulasi dan menilai keandalan penghitungan penghasilan (Beneish, 1999). Namun demikian, hasil perhitungan M-Score masih memerlukan penelitian lebih lanjut untuk dapat menghasilkan kesimpulan yang benar. Penelitian lebih lanjut bertujuan untuk memastikan apakah penyimpangan yang terdeteksi dari hasil perhitungan $M$-Score disebabkan karena adanya manipulasi pada laporan keuangan atau karena faktor-faktor lainnya (Beneish, 1999).

Model perhitungan $M$-Score terdiri dari 8 (delapan) variabel perhitungan. Berikut ini formula perhitungan dari masing-masing variabel $M$-Score sebagaimana yang dikemukakan oleh Beneish (1999), yaitu sebagai berikut.

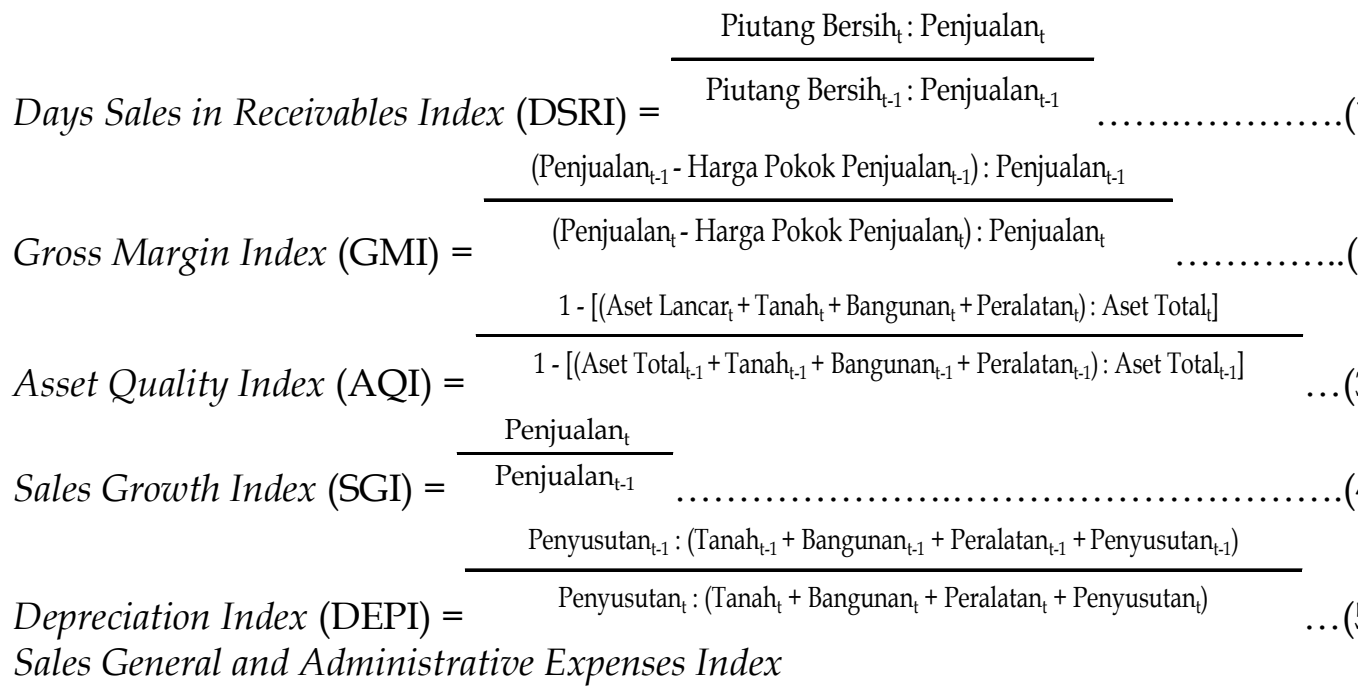

Beban Penjualan, Umum, dan Administrasi $:$ Penjualan $_{t}$

$(\mathrm{SGAI})=\quad$ Beban Penjualan, Umum, dan Administrasi $\mathrm{t}_{\mathrm{t}-1}:$ Penjualan $_{\mathrm{t}-1}$ 
Berdasarkan kajian literatur, model perhitungan Beneish $M$-Score telah digunakan dalam penelitian yang dilakukan oleh Annisa (2017), Hantono (2018), serta Christy \& Stephanus (2018). Penelitian tersebut bertujuan untuk menentukan kategori manipulator, grey company, dan non manipulator. Ketiga peneliti tersebut menggunakan metode penelitian kuantitatif dalam penelitiannya. Metode dokumentasi digunakan untuk mengumpulkan data penelitian. Penelitian tersebut menghasilkan temuan penelitian dalam bentuk kategori manipulator, grey company, dan non manipulator.

Penelitian ini berbeda dengan penelitian sebelumnya yang telah dilakukan oleh Annisa (2017), Hantono (2018), serta Christy \& Stephanus (2018). Metode kualitatif dipilih sebagai metode dalam penelitian ini. Data keuangan diperoleh melalui formulir pengumpulan data. Model perhitungan Beneish $M$ Score juga digunakan dalam penelitian ini. Namun demikian, penelitian ini berusaha untuk tidak hanya mengelompokan hasil temuan penelitian ke dalam kategori manipulator dan non manipulator. Analisis lebih lanjut dilakukan pada tiap-tiap variabel pembentuk $M$-Score.

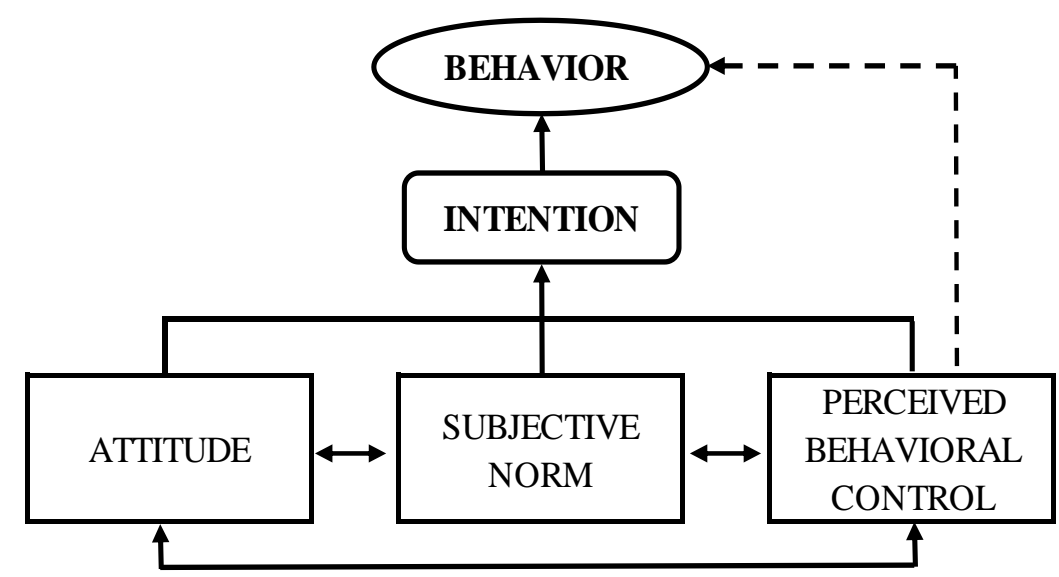

\section{Sumber: Azjen, 1991}

\section{Gambar 1. Kerangka Theory of Planned Behavior (TPB)}

Teori utama yang digunakan dalam penelitian ini adalah Theory of Planned Behavior ("TPB") atau Teori Perilaku Terencana. TPB dicetuskan pertama kali oleh Icek Ajzen pada tahun 1991. Teori ini pada dasarnya menjelaskan bahwa perilaku (behavior) seseorang dibentuk melalui niat (intention) yang dimilikinya. Gambar 1 menjelaskan kerangka terbentuknya perilaku seseorang berdasarkan TPB (Ajzen, 1991). Niat (intention) dapat diprediksi melalui sikap (attitudes), norma subjektif (subjective norm), dan kendali perilaku yang dipersepsikan (perceived behavioral control). Sikap (attitudes) mengacu pada sejauh mana seseorang memiliki evaluasi atau penilaian yang menguntungkan (favorable) atau tidak menguntungkan (unfavorable) pada suatu perilaku. Norma 
subjektif (subjective norm) sebagai faktor sosial, mengacu pada tekanan sosial yang dirasakan untuk melakukan atau tidak melakukan suatu perilaku. Kendali perilaku yang dipersepsikan (perceived behavioral control) mengacu pada tersedianya sumber daya atau kemampuan (ability) bagi seseorang untuk menentukan perilaku yang ingin dilakukan.

Menurut Azjen (1991) kendali perilaku yang dipersepsikan memegang peran penting dalam TPB. Suatu perilaku dapat dibentuk hanya berdasarkan munculnya kendali perilaku yang dipersepsikan. Berdasarkan penelitian yang dilakukan oleh Bandura, Adams, \& Beyer (1977) dalam Ajzen (1991) dan Bandura, et al., (1980) dalam Ajzen (1991), bahwa perilaku seseorang sangat dipengaruhi oleh keyakinan mereka pada kemampuan untuk melakukannya (yaitu, melalui kontrol perilaku yang dirasakan). Menurut TPB, suatu perilaku dapat dibentuk secara langsung melalui kendali perilaku yang dipersepsikan dan niat terhadap suatu perilaku.

Berdasarkan kajian literatur, terdapat beberapa penelitian mengenai kepatuhan pajak. Masalah kepatuhan pajak tidak dapat dipisahkan dari penerapan sistem pemungutan pajak (self-assessment system) di Indonesia. Tingkat kepatuhan pajak yang tinggi menurut Ilyas \& Wicaksono (2015), dapat menjamin terlaksananya sistem self-assessment berjalan dengan baik. Saputri \& Kiswara (2019) dan Saputra (2019) melakukan penelitian dengan tema kepatuhan pajak berdasarkan perspektif Teori Perilaku Terencana. Populasi penelitian yang dipilih adalah WP Orang Pribadi. Metode analisis data dilakukan dengan metode kuantitatif. Penelitian oleh Saputri \& Kiswara (2019) menghasilkan kesimpulan bahwa niat wajib pajak untuk melakukan pelanggaran pajak berpengaruh terhadap perilaku ketidakpatuhan pajak WP. Sedangkan hasil penelitian Saputra (2019) menghasilkan kesimpulan bahwa perilaku kepatuhan pajak merupakan perilaku yang didasari oleh niat WP untuk berperilaku patuh terhadap pajak dan sebaliknya.

Penelitian ini berbeda dengan penelitian sebelumnya yang telah dilakukan oleh Saputri \& Kiswara (2019) maupun Saputra (2019) mengenai perilaku terencana terhadap kepatuhan pajak. Populasi penelitian yang dipilih dalam penelitian ini adalah WP Badan. Metode analisis data dilakukan dengan metode Kualitatif. Perilaku yang ditunjukan oleh data keuangan dan non keuangan, diharapkan dapat menghasilkan pemetaan kepatuhan pajak dari WP dalam menghadapi fenomena rendahnya realisasi penerimaan pajak dan meningkatnya kinerja pemeriksaan pajak.

\section{METODE PENELITIAN}

Strategi penelitian yang digunakan dalam penelitian ini berupa studi kasus. Menurut Yin (2009) dalam Afrizal (2017), penelitian studi kasus adalah suatu cara untuk menyelidiki terjadinya sebuah fenomena di kehidupan nyata yang konteksnya belum dapat dipastikan dan dilakukan dengan memanfaatkan bermacam sumber data. Penelitian studi kasus menurut Gunawan (2017) adalah meneliti fenomena secara komprehensif sesuai kondisi yang terjadi dengan memanfaatkan data dari berbagai sumber. Berdasarkan hal tersebut, maka strategi penelitian ini dilakukan dengan pendekatan studi kasus yang dapat 
merepresentasikan masalah rendahnya kepatuhan pajak sebagaimana telah dijelaskan pada bagian Pendahuluan.

Penelitian ini dilakukan dengan menggunakan pendekatan metode gabungan/kombinasi (mixed method). Mixed method merupakan gabungan antara metode kuantitatif dengan kualitatif dalam rangka menjawab masalah penelitian (Shauki, 2018). Metode kombinasi dimulai dengan menggunakan metode kuantitatif dalam memetakan data penelitian sesuai dengan rumusan masalah dan kemudian dengan pendekatan kualitatif untuk menghasilkan kesimpulan penelitian.

Penelitian ini menggunakan sumber data primer dan sekunder. Data sekunder merupakan nilai variabel data keuangan tahun 2017 dari WP. Data keuangan ini diperoleh secara tidak langsung dari unit analisis. Data lainnya yang bersifat non keuangan merupakan data primer yang diperoleh langsung dari unit analisis. Instrumen penelitian dibutuhkan dalam rangka pengumpulan data di dalam suatu penelitian.

Teknik pengumpulan data pada penelitian ini menggunakan teknik dokumentasi dalam bentuk Formulir Pengumpulan Data Penelitian (FPDP) atau Formulir 1 dan Pengumpulan Data Penelitian Lanjutan (FPDPL) atau Formulir 2. Menurut Sugiyono (2016), dokumentasi adalah salah satu teknik pengumpulan data dan informasi dalam bentuk buku, arsip, dokumen, laporan, serta keterangan yang dapat mendukung suatu penelitian.

Teknik analisis data yang digunakan dalam penelitian ini adalah analisis deskriptif. Teknik ini digunakan untuk menganalisis data dengan cara mendeskripsikan atau menggambarkan data yang telah dikumpulkan apa adanya tanpa berusaha untuk menyimpulkan data tersebut (Sugiyono, 2016). Metode analisis deskriptif dalam penelitian ini digunakan untuk memetakan kepatuhan pajak dan memberikan keyakinan yang menguatkan atas hasil pemetaan tersebut.

Analisis data dilakukan setelah data dikumpulkan melalui Formulir 1 dan 2. Hasil rekapitulasi pada Formulir 1 akan menghasilkan 2 (dua) kategori, yaitu manipulator (tidak patuh) dan non manipulator (patuh). Tindak lanjut analisis data difokuskan pada hasil temuan pada masing-masing nilai variabel M-Score. Analisis data lanjutan dilakukan berdasarkan data yang diperoleh melalui Formulir 2. Data yang diperoleh dari Formulir 2 akan digunakan sebagai pendukung temuan yang diperoleh dari Formulir 1. Kesimpulan akan diperoleh setelah mempertimbangkan hasil analisis data keuangan dan data non keuangan dari data penelitian yang diperoleh.

Penelitian ini menggunakan single case unit analysis. Unit analisis atau objek penelitian yang dipilih dalam ini adalah Kantor Pelayanan Pajak (KPP) Jakarta yang berlokasi di wilayah DKI Jakarta. Pemilihan KPP Jakarta sebagai unit analisis berdasarkan pertimbangan terkait dengan akses data penelitian, jenis usaha, status audit Laporan Keuangan dari data penelitian yang akan diperoleh dalam penelitian ini.

\section{HASIL DAN PEMBAHASAN}

Tabel 2, menampilkan data yang diperoleh penulis selama periode pengumpulan data dan hasil pengolahan data dengan menggunakan $M$-Score. Nilai M-Score 
dihasilkan dari perhitungan 8 variabel, yaitu DSRI, GMI, AQI, SGI, DEPI, SGAI, LVGI, dan TATA. Berdasarkan nilai indeks dari 8 variabel $M$-Score di setiap data, penulis memasukkan nilai tersebut ke dalam rumus baku $M$-Score menurut Beneish, Lee, \& Nichols (2013) maupun Beneish \& Vorst (2020) sebagai berikut. $M-S c o r e=-4,84+0,920 \mathrm{DSRI}+0,528 \mathrm{GMI}+0,404 \mathrm{AQI}+0,892 \mathrm{SGI}+0,115 \mathrm{DEPI}-$ 0,172SGAI + 4,679TATA - 0,327LVGI

Penentuan nilai $M$-Score menggunakan kategori $M$-Score yang juga digunakan dalam penelitian Beneish, Lee, \& Nichols (2013) maupun Beneish \& Vorst (2020). Berdasarkan penelitian tersebut, nilai $M$-Score dengan hasil > 1,78 dikategorikan sebagai manipulator dan nilai $M$-Score dengan hasil $\leq-1,78$ dikategorikan sebagai non manipulator.

Tabel 2. Analisis Data Keuangan

\begin{tabular}{|c|c|c|c|c|c|c|c|c|c|c|c|}
\hline \multirow{2}{*}{ No. } & \multirow{2}{*}{$\begin{array}{l}\text { Kode } \\
\text { Data }\end{array}$} & \multicolumn{9}{|c|}{ Variabel M-Score } & \multirow{2}{*}{ Kategori Data } \\
\hline & & DSRI & GMI & AQI & SGI & DEPI & SGAI & LVGI & TATA & M-Score & \\
\hline 1 & 1-DG & 1.853 & 0.979 & 1.044 & 0.818 & 1.038 & 1.174 & 0.697 & 0.870 & 2.292 & Manipulator \\
\hline 2 & 2-DG & 0.801 & 0.974 & 0.169 & 1.010 & 0.699 & 1.133 & 1.107 & 0.095 & -2.652 & Non Manipulator \\
\hline 3 & 3-DG & 1.094 & 0.938 & 1.433 & 0.792 & 0.651 & 1.054 & 0.812 & 0.606 & 0.412 & Manipulator \\
\hline 4 & 4-DG & 1.058 & 0.995 & 1.230 & 1.361 & 0.731 & 0.919 & 0.806 & -0.094 & -2.406 & Non Manipulator \\
\hline 5 & 5-DG & 1.370 & 0.764 & 1.097 & 0.929 & 1.199 & 1.164 & 0.880 & 0.386 & -0.450 & Manipulator \\
\hline 6 & 6-DG & 1.278 & 0.986 & 1.046 & 0.924 & 0.795 & 1.015 & 0.894 & -0.084 & -2.665 & Non Manipulator \\
\hline 7 & 7-DG & 1.113 & 1.024 & -0.740 & 1.071 & 1.193 & 0.983 & 1.161 & -0.015 & -3.101 & Non Manipulator \\
\hline 8 & 1-IN & 0.739 & -6.982 & 1.182 & 0.755 & 0.942 & 0.989 & 1.084 & -0.137 & -7.752 & Non Manipulator \\
\hline 9 & 2-IN & 1.678 & 1.022 & 0.745 & 0.981 & 1.172 & 0.708 & 0.723 & 0.588 & 0.944 & Manipulator \\
\hline 10 & 3-IN & 0.992 & 1.015 & 1.270 & 1.142 & 0.915 & 1.041 & 0.929 & -0.064 & -2.536 & Non Manipulator \\
\hline 11 & 4-IN & 1.570 & 1.221 & 7.642 & 1.029 & 0.846 & 1.071 & 0.985 & -0.330 & -0.700 & Manipulator \\
\hline 12 & 1-JS & 0.726 & 1.147 & 0.000 & 1.548 & 1.193 & 0.718 & 1.389 & -0.086 & -3.028 & Non Manipulator \\
\hline 13 & 2-JS & 3.842 & 1.000 & 0.000 & 1.338 & 1.286 & 0.998 & 1.323 & 0.018 & 0.044 & Manipulator \\
\hline 14 & 3-JS & 1.015 & 1.063 & 1.268 & 1.037 & 0.847 & 0.914 & 1.078 & -0.082 & -2.704 & Non Manipulator \\
\hline 15 & 4-JS & 0.677 & 1.020 & 1.493 & 1.000 & 0.522 & 0.965 & 0.782 & -0.121 & -3.112 & Non Manipulator \\
\hline 16 & 5-JS & 0.705 & 0.884 & 0.331 & 1.652 & 0.927 & 0.772 & 1.070 & 0.111 & -1.976 & Non Manipulator \\
\hline
\end{tabular}

Sumber: Data Penelitian, 2020

Catatan:

Kode data "DG" : : Jenis usaha Perdagangan jumlah 7 data

Kode data "IN" : Jenis usaha Industri jumlah 4 data

Kode data "JS" : : Jenis usaha Jasa jumlah 5 data 
Berdasarkan hasil perhitungan dan kategori nilai M-Score pada Tabel 2, penulis menemukan fakta bahwa masing-masing data jenis usaha (perdagangan, industri, maupun jasa) memiliki kategori sebagai manipulator maupun non manipulator. Sebaran jenis usaha dan kategori data sebagaimana dimaksud adalah sebagai berikut. Enam data dikategorikan sebagai manipulator. Data tersebut terdiri dari 3 data dengan jenis usaha perdagangan, 2 data dengan jenis usaha industri, dan satu data dengan jenis usaha jasa; dan Sepuluh data dikategorikan sebagai non manipulator. Data tersebut terdiri dari 4 data dengan jenis usaha perdagangan, 2 data dengan jenis usaha industri, dan 4 data dengan jenis usaha jasa.

Temuan penelitian di atas menunjukkan bahwa berdasarkan model perhitungan $M$-Score, kurang dari 50\% jumlah data pada setiap jenis usaha terindikasi telah melakukan manipulasi pada laporan keuangan. Dalam kaitannya dengan perpajakan, indikasi manipulasi pada laporan keuangan secara tidak langsung berdampak pada dasar perhitungan pajak terutang pada tahun pajak tertentu. Berdasarkan perhitungan $M$-Score, penulis berpendapat bahwa hampir 50\% dari jumlah data keuangan yang digunakan dalam penelitian ini menunjukkan adanya indikasi kepatuhan pajak yang rendah.

Hasil penelitian ini tidak berhenti dengan hanya mengandalkan hasil pengelompokan data ke dalam kategori manipulator atau non manipulator. Penulis melakukan analisis lebih lanjut terhadap nilai indeks dari tiap variabel M-Score sebagaimana terdapat pada Tabel 2, Tujuannya adalah untuk menghasilkan temuan penelitian yang dapat diandalkan dalam rangka melakukan evaluasi perilaku kepatuhan pajak dari data keuangan yang tersedia.

Analisis lanjutan dilakukan terhadap masing-masing variabel pembentuk nilai $M$-Score. Berdasarkan hasil yang ditunjukan pada Tabel 2, diperoleh hasil analisis sebagai berikut. Kolom Days Sales in Receivables Index ("DSRI") menunjukan bahwa terdapat 10 (sepuluh) data dengan nilai indeks lebih dari 1 dan 6 (enam) data dengan nilai indeks sampai dengan 1. Nilai wajar dalam perhitungan DSRI adalah pada rentang nilai sampai dengan 1 (Beneish, 1999). 10 (sepuluh) data dengan nilai DSRI lebih besar dari 1 terdiri dari 6 (enam) data dengan indikasi sebagai manipulator dan 4 (empat) data dengan indikasi sebagai non manipulator. Kesepuluh data tersebut diindikasikan telah menggunakan kemampuan atau sumber daya yang dimilikinya untuk menunjukan perilaku kepatuhan yang rendah terkait dengan jumlah Piutang Bersih dan/atau Penjualan yang dicatat pada laporan keuangan tahun 2017.

Kolom Gross Margin Index ("GMI") menunjukan bahwa terdapat 7 (tujuh) data dengan nilai indeks lebih dari 1 dan 9 (sembilan) data dengan nilai indeks sampai dengan 1. Nilai wajar dalam perhitungan GMI adalah pada rentang nilai sampai dengan 1 (Beneish, 1999). 7 (tujuh) data dengan nilai GMI lebih besar dari 1 terdiri dari 2 (dua) data dengan indikasi sebagai manipulator dan 5 (lima) data dengan indikasi sebagai non manipulator. Ketujuh data tersebut diindikasikan telah menggunakan kemampuan atau sumber daya yang dimilikinya (kendali perilaku yang dipersepsikan) untuk menunjukan perilaku kepatuhan yang rendah terkait dengan jumlah Penjualan dan/atau Harga Pokok Penjualan yang dicatat pada laporan keuangan tahun 2017. 
Kolom Asset Quality Index ("AQI") menunjukan bahwa terdapat 10 (sepuluh) data dengan nilai indeks lebih dari 1 dan 6 (enam) data dengan nilai indeks sampai dengan 1. Nilai wajar dalam perhitungan AQI adalah pada rentang nilai sampai dengan 1 (Beneish, 1999). 10 (sepuluh) data dengan nilai AQI lebih besar dari 1 terdiri dari 4 (empat) data dengan indikasi sebagai manipulator dan 6 (enam) data dengan indikasi sebagai non manipulator. Kesepuluh data tersebut diindikasikan telah menggunakan kemampuan atau sumber daya yang dimilikinya (kendali perilaku yang dipersepsikan) untuk menunjukan perilaku kepatuhan yang rendah terkait dengan jumlah Aset Lancar, Aset Tetap (Tanah, Bangunan, dan Peralatan), dan/atau Total Aset yang dicatat pada laporan keuangan tahun 2017.

Kolom Sales Growth Index ("SGI") menunjukan bahwa terdapat 9 (sembilan) data dengan nilai indeks lebih dari 1 dan 7 (tujuh) data dengan nilai indeks sampai dengan 1. Nilai wajar dalam perhitungan SGI adalah pada rentang nilai lebih besar dari 1 (Beneish, 1999). 7 (tujuh) data dengan nilai SGI sampai dengan 1 terdiri dari 4 (empat) data dengan indikasi sebagai manipulator dan 3 (tiga) data dengan indikasi sebagai non manipulator. Ketujuh data tersebut diindikasikan telah menggunakan kemampuan atau sumber daya yang dimilikinya (kendali perilaku yang dipersepsikan) untuk menunjukan perilaku kepatuhan yang rendah terkait dengan jumlah Penjualan yang dicatat pada laporan keuangan tahun 2017.

Kolom Depreciation Index ("DEPI") menunjukan bahwa terdapat 6 (enam) data dengan nilai indeks lebih dari 1 dan 10 (sepuluh) data dengan nilai indeks sampai dengan 1. Nilai wajar dalam perhitungan DEPI adalah pada rentang nilai lebih besar dari 1 (Beneish, 1999). 10 (sepuluh) data dengan nilai DEPI sampai dengan 1 terdiri dari 2 (dua) data dengan indikasi sebagai manipulator dan 8 (delapan) data dengan indikasi sebagai non manipulator. Kesepuluh data tersebut diindikasikan telah menggunakan kemampuan atau sumber daya yang dimilikinya (kendali perilaku yang dipersepsikan) untuk menunjukan perilaku kepatuhan yang rendah terkait dengan jumlah Penyusutan dan Aset Tetap (Tanah, Bangunan, dan Peralatan) yang dicatat pada laporan keuangan tahun 2017.

Kolom Sales General and Administrative Expenses Index ("SGAI") menunjukan bahwa terdapat 7 (tujuh) data dengan nilai indeks lebih dari 1 dan 9 (sembilan) data dengan nilai indeks sampai dengan 1. Nilai wajar dalam perhitungan SGAI adalah pada rentang nilai sampai dengan 1 (Beneish, 1999). 7 (tujuh) data dengan nilai SGAI lebih dari 1 terdiri dari 4 (empat) data dengan indikasi sebagai manipulator dan 3 (tiga) data dengan indikasi sebagai non manipulator. Ketujuh data tersebut diindikasikan telah menggunakan kemampuan atau sumber daya yang dimilikinya (kendali perilaku yang dipersepsikan) untuk menunjukan perilaku kepatuhan yang rendah terkait dengan jumlah Beban Penjualan, Umum dan Adminstrasi dan/atau Penjualan yang dicatat pada laporan keuangan tahun 2017.

Kolom Leverage Index ("LVGI") menunjukan bahwa terdapat 7 (tujuh) data dengan nilai indeks lebih dari 1 dan 9 (sembilan) data dengan nilai indeks sampai dengan 1. Nilai wajar dalam perhitungan LVGI adalah pada rentang nilai sampai dengan 1 (Beneish, 1999). 7 (tujuh) data dengan nilai LVGI lebih 
dari 1 terdiri dari satu data dengan indikasi sebagai manipulator dan 6 (enam) data dengan indikasi sebagai non manipulator. Ketujuh data tersebut diindikasikan telah menggunakan kemampuan atau sumber daya yang dimilikinya (kendali perilaku yang dipersepsikan) untuk menunjukan perilaku kepatuhan yang rendah terkait dengan jumlah Total Utang Lancar, Total Utang Jangka Panjang, dan/atau Total Aset yang dicatat pada laporan keuangan tahun 2017.

Kolom Total Accruals to Total Assets ("TATA") menunjukan bahwa terdapat 7 (tujuh) data dengan nilai indeks lebih dari 0 dan 9 (sembilan) data dengan nilai indeks sampai dengan 0. Nilai wajar dalam perhitungan TATA adalah pada rentang nilai sampai dengan 0 (Beneish, 1999). 7 (tujuh) data dengan nilai TATA lebih dari 0 terdiri dari 5 (lima) data dengan indikasi sebagai manipulator dan 2 (dua) data dengan indikasi sebagai non manipulator. Ketujuh data tersebut diindikasikan telah menggunakan kemampuan atau sumber daya yang dimilikinya (kendali perilaku yang dipersepsikan) untuk menunjukan perilaku kepatuhan yang rendah terkait dengan jumlah Total Akrual dan/atau Total Aset yang dicatat pada laporan keuangan tahun 2017.

Analisis lanjutan dilakukan pada masing-masing variabel pembentuk $M$ Score yaitu, DSRI, GMI, AQI, SGI, DEPI, SGAI, LVGI, dan TATA. Analisis ini menghasilkan temuan bahwa di setiap data penelitian terdapat variabel dengan nilai indeks yang tidak sesuai standar menurut Beneish (1999). Sebanyak 10 (sepuluh) data penelitian pada variabel DSRI, AQI, dan DEPI dan 7 (tujuh) data penelitian pada variabel GMI, SGI, SGAI, LVGI, dan TATA menghasilkan nilai indeks yang tidak sesuai standar.

Hasil analisis lanjutan menunjukan bahwa perilaku data keuangan dapat digambarkan dengan jelas berdasarkan analisis pada masing-masing variabel pembentuk $M$-Score. Oleh karena itu, analisis ini lebih tepat digunakan untuk mengevaluasi kepatuhan pajak dibandingkan dengan hasil M-Score berdasarkan kategori manipulator atau non manipulator.

Analisis lanjutan mengindikasikan bahwa setiap data penelitian telah menggunakan kemampuan atau sumber daya yang dimilikinya untuk menunjukan beberapa perilaku kepatuhan yang tidak wajar. Perilaku tidak wajar berkaitan dengan hasil nilai indeks yang tidak sesuai dengan standar menurut Beneish (1999). Berdasarkan hal tersebut, dapat dikatakan bahwa seluruh data penelitian atau WP diindikasikan memiliki kepatuhan pajak yang rendah.

Data non keuangan yang diperoleh terkait dengan status audit atas laporan keuangan dan batasan peredaran usaha. Hasil penelitian pada Tabel 3, menunjukan bahwa terdapat 11 (sebelas) dari 16 (enam belas) data penelitian yang telah menyerahkan laporan keuangan tahun 2017 kepada Akuntan Publik untuk diaudit. Hasil lain menunjukan bahwa sebanyak 14 (empat belas) dari 16 (enam belas) data penelitian memiliki peredaran usaha dengan jumlah paling sedikit Rp50 miliar. Pasal 68 ayat (1) huruf e Undang-Undang Perseroan Terbatas ("UU PT") mewajibkan audit atas laporan keuangan bagi perseroan yang memiliki aset dan/atau jumlah peredaran usaha dengan jumlah paling sedikit Rp50 miliar (Republik Indonesia, 2007). Berdasarkan ketentuan tersebut, batasan peredaran usaha dan kewajiban audit atas laporan keuangan merupakan acuan yang dapat digunakan dalam mengevaluasi kepatuhan pajak. 
Tabel 3. Perolehan Data Non-Keuangan

JENIS DATA

\begin{tabular}{ccc} 
Kode Data & $\begin{array}{c}\text { Laporan Keuangan di audit oleh } \\
\text { Akuntan Publik }\end{array}$ & $\begin{array}{c}\text { Memiliki Peredaran Usaha paling } \\
\text { sedikit Rp50 miliar }\end{array}$ \\
\hline 1-DG & X & $\checkmark$ \\
2-DG & X & $\checkmark$ \\
3-DG & $\checkmark$ & $\checkmark$ \\
4-DG & $\checkmark$ & $\checkmark$ \\
5-DG & $\checkmark$ & $\checkmark$ \\
6-DG & $\checkmark$ & $\checkmark$ \\
7-DG & $\checkmark$ & $\checkmark$ \\
1-IN & $\checkmark$ & $x$ \\
2-IN & $\checkmark$ & $\checkmark$ \\
3-IN & $\checkmark$ & $\checkmark$ \\
4-IN & $\checkmark$ & $\checkmark$ \\
1-JS & $x$ & $x$ \\
2-JS & $x$ & $\checkmark$ \\
3-JS & $\checkmark$ & $\checkmark$ \\
4-JS & $x$ & $\checkmark$ \\
\hline
\end{tabular}

Sumber: Data Penelitian, 2020

Penelitian ini menemukan adanya 4 (empat) data penelitian yang memiliki jumlah peredaran usaha pada tahun 2017 paling sedikit sebesar Rp50 miliar namun tidak menyerahkan laporan keuangan tahun 2017 kepada Akuntan Publik untuk diaudit. Keempat data tersebut telah membuktikan adanya kendali perilaku yang dipersepsikan dari WP untuk tidak patuh terhadap ketentuan yang berlaku. WP telah menunjukan penggunaan sumberdaya dan kemampuan yang dimilikinya untuk tidak menjalankan ketentuan sebagaimana diatur dalam Pasal 68 ayat (1) huruf e UU PT.

Analisis data keuangan dalam penelitian ini menggunakan model perhitungan Beneish $M$-Score. Hasil analisis menunjukan bahwa hampir 50\% dari jumlah data penelitian diindikasikan sebagai manipulator dan lebih dari $50 \%$ jumlah data penelitian diindikasikan sebagai non manipulator. Hasil tersebut juga mengindikasikan adanya perilaku kepatuhan pajak yang rendah pada kurang dari $50 \%$ jumlah data penelitian karena termasuk dalam kategori manipulator.

Analisis lanjutan terhadap data keuangan dilakukan terhadap beberapa variabel pembentuk $M$-Score. Hasil analisis menunjukan bahwa di setiap kategori 
data penelitian (manipulator atau non manipulator) terdapat variabel pembentuk $M$-Score yang memiliki nilai indeks yang tidak sesuai dengan standar $M$-Score. Analisis ini mengindikasikan adanya penggunaan kemampuan atau sumber daya yang dimiliki untuk menunjukan perilaku kepatuhan pajak yang rendah pada seluruh data penelitian.

Analisis terhadap data non keuangan menggunakan variabel status audit atas laporan keuangan dan batasan jumlah peredaran usaha. Hasil analisis menunjukan bahwa data non keuangan dapat menggambarkan dengan jelas penggunaan sumber daya atau kemampuan yang dimiliki oleh data penelitian untuk menentukan perilaku kepatuhan pajak. Analisis ini mengindikasikan adanya perilaku kepatuhan pajak yang rendah pada data penelitian yang tidak menyerahkan laporan keuangan perseroan kepada Auditor Independen dan memiliki peredaran usaha paling sedikit sebesar Rp50 miliar.

\section{SIMPULAN}

Berdasarkan beberapa penjelasan sebelumnya, ringkasan yang dapat diambil dari penelitian ini adalah sebagai berikut. Hasil perhitungan M-Score menunjukan bahwa hampir 50\% dari jumlah data penelitian diindikasikan memiliki perilaku kepatuhan pajak yang rendah. Indikasi tersebut berdasarkan pengelompokan data ke dalam kategori manipulator atau non manipulator. Hasil analisis terhadap 8 (delapan) variabel pembentuk $M$-Score menunjukan bahwa seluruh data penelitian diindikasikan memiliki perilaku kepatuhan pajak yang rendah. Indikasi tersebut berdasarkan nilai indeks yang dihasilkan dari masing-masing variabel pembentuk $M$-Score pada tiap data penelitian. Hasil analisis terhadap data non keuangan menunjukan bahwa terdapat indikasi perilaku kepatuhan pajak yang rendah pada beberapa data penelitian. Perilaku tersebut terkait dengan tidak dipenuhinya ketentuan mengenai kewajiban audit atas laporan keuangan dan batasan jumlah peredaran usaha. Hasil indikasi perilaku kepatuhan pajak yang rendah berdasarkan analisis keuangan dan non keuangan, memperkuat dugaan terjadinya realisasi penerimaan pajak yang belum optimal dan tingginya pemeriksaan pajak.

Berdasarkan ringkasan penelitian tersebut, dapat disimpulkan bahwa perilaku data keuangan dan non keuangan dari WP menunjukan adanya indikasi kepatuhan pajak yang rendah. Selanjutnya, tindakan pemeriksaan pajak sangat diperlukan untuk menguji kepatuhan pemenuhan kewajiban perpajakan dari WP dan meningkatkan penerimaan negara dari sektor pajak. Berdasarkan hasil penelitian tersebut, terbukti bahwa rendahnya realisasi penerimaan pajak dan tingginya pemeriksaan pajak disebabkan karena rendahnya tingkat kepatuhan pajak yang dimiliki oleh Wajib Pajak.

Penelitian ini dalam prosesnya, tidak luput dari adanya keterbatasan. Adapun keterbatasan yang dimaksud adalah sebagai berikut. Analisis data keuangan yang hanya menggunakan model perhitungan Beneish M-Score. Tahun yang digunakan untuk penelitian hanya Tahun Pajak 2017 atau satu Tahun Pajak. Jumlah variabel data non keuangan yang digunakan sebanyak 2 (dua) variable yaitu, status audit atas laporan keuangan dan batasan jumlah peredaran usaha. 
Beberapa saran yang dapat diberikan bagi para peneliti selanjutnya adalah sebagai berikut. Menggunakan model perhitungan lain untuk menganalisis dan mengevaluasi perilaku kepatuhan pajak berdasarkan data keuangan yang tersedia. Menggunakan lebih dari satu Tahun Pajak untuk mendapatkan hasil penelitian yang lebih akurat. Menambah variabel data nonkeuangan dalam rangka memperoleh hasil penelitian yang lebih baik dan akurat.

\section{REFERENSI}

Afrizal. (2017). Metode Penelitian Kualitatif: Sebuah Upaya Mendukung Penggunaan Penelitian Kualitatif dalam Berbagai Disiplin Ilmu. In Depok: Rajawali Pers.

Ajzen, I. (1991). The Theory of Planned Behavior. Organizational Behavior and Human Decision Processes, 50(2), 179-211.

Annisa, N. (2017). Pendeteksian Kecurangan Laporan Keuangan dengan Analisis Beneish M-Score Model pada Perusahaan Perdagangan Eceran yang Terdaftar di Bursa Efek Indonesia Tahun 2014. Jurnal Profita: Kajian Ilmu Akuntansi, 5(7).

Bandura, A., Adams, N. E., \& Beyer, J. (1977). Cognitive processes mediating behavioral change. Journal of Personality and Social Psychology, 35, 125-139.

Bandura, A., Adams, N. E., Hardy, A. B., \& Howells, G. N. (1980). Tests of the generality of self-efficacy theory. Cognitive Theraphy and Research, 4, 39-66.

Beneish, Messod D. (1999). The Detection of Earnings Manipulation. Financial Analysist Journal, 55(5), 24-36.

Beneish, Messod D., Lee, C. M. C., \& Nichols, D. C. (2013). Earnings Manipulation and Expected Returns. Financial Analysts Journal, 69(2), 57-82.

Beneish, Messod Daniel, \& Vorst, P. (2020). The Cost of Fraud Prediction Errors. Kelley School of Business Research Paper, 2020, 55.

Christy, Y. E., \& Stephanus, D. S. (2018). Pendeteksian Kecurangan Laporan Keuangan dengan Beneish M-Score pada Perusahaan Perbankan Terbuka. Jurnal Akuntansi Bisnis, 16(1), 19-41.

Direktorat Jenderal Pajak. (2016). Laporan Kinerja Direktorat Jenderal Pajak Tahun 2016. https://pajak.go.id/sites/default/files/2019-04/LAKIN DJP 2016.pdf

Direktorat Jenderal Pajak. (2017). Laporan Kinerja Direktorat Jenderal Pajak Tahun 2017. https:// pajak.go.id/sites/default/files/2019-03/LAKIN DJP 2017.pdf

Gunawan, I. (2017). Metode Penelitian Kualitatif: Teori dan Praktik. In Jakarta: Bumi Aksara.

Hantono. (2018). Deteksi Financial Statement Fraud Melalui Model Beneish Pada Perusahaan BUMN. JMBI UNSRAT (Jurnal Ilmiah Manajemen Bisnis Dan Inovasi Universitas Sam Ratulangi)., 135-150.

Ilyas, W. B., \& Wicaksono, P. (2015). Pemeriksaan Pajak. In Jakarta: Mitra Wacana Media.

Kementerian Keuangan. (2016). Menkeu: Pajak Merupakan Tulang Punggung Nasional.

Kemenkeu.Go.Id. https://www.kemenkeu.go.id/publikasi/berita/menkeu-pajakmerupakan-tulang-punggung-nasional/

Kementerian Keuangan. (2019). Ringkasan APBN 2000-2017. Kemenkeu.Go.Id. http://www.data-apbn.kemenkeu.go.id/Dataset/Details/1011 
Republik Indonesia. (2007). Undang-Undang Nomor 40 Tahun 2007 Tentang Perseroan Terbatas. Lembaran Negara RI Tahun 2007.

Saputra, H. (2019). Analisa Kepatuhan Pajak Dengan Pendekatan Teori Perilaku Terencana (Theory of Planned Behavior) Terhadap Wajib Pajak Orang Pribadi Di Provinsi DKI Jakarta. Jurnal Muara Ilmu Ekonomi Dan Bisnis, 3(1), 47-58.

Saputri, A. M., \& Kiswara, E. (2019). Perspektif Teori Perilaku Terencana Terhadap Niat Wajib Pajak Orang Pribadi untuk Melakukan Pelanggaran Pajak. Diponegoro Journal of Accounting, 8(1), 2.

Shauki, E. R. (2018). Qualitative and Mixed-Method Research Analysis using NVIVO11. In Case Writing and Methodology (p. Print).

Sugiyono. (2016). Metode Penelitian Kuantitatif, Kualitatif dan R\&D. In Bandung: CV Alfabeta.

Yin, R. K. (2009). Studi Kasus: Desain dan Metode. In Jakarta: Raja Grafindo Perkasa. 